\title{
PENGARUH PENUNDAAN WAKTU TERHADAP HASIL URINALISIS SEDIMEN URIN
}

\author{
Tadjuddin Naid, Fitriani Mangerangi, Hanifah Almahdaly \\ Fakultas Farmasi Universitas Hasanuddin Makassar \\ Email : tadjuddinnaid@yahoo.co.id
}

\begin{abstract}
A research about the effect of time delays on the result of urinalysis urine sediment. This research is aimed to determine the presence or absence effect of delay on the result of urine sediment eximination. This research used cross sectional study. Total amount sample was 37 samples and using urine at the time. A microscopic examination of a sample ( urine sediment) by the method of Shih-Yung. The research result showed that the average number of leukocytes in immediate examination, 2 hour, amd 3 hour are 1,29/ $\mu \mathrm{l}, 1.05 / \mu \mathrm{l}, 0,89 / \mu \mathrm{l}$ respective, the average numberof erythroctes immediate examination, 2 hour, and 3 hour are 0,70/ $\mu$ l, $0.59 /$ $\mu \mathrm{l}, 0,48 / \mu \mathrm{l}$, respective, the average number of epitheliel cell examination immediate, 2 hour, and 3 hour are 9,70/LPB, 8,51/LPB, 7,54/LPB respective. By One Way Anova statistical Test, test value $P>0,05$ with a value of $F$ count $<F$ table. Based one data the result of study then it can be conclusion that are no signifikan effect of time delay urine sediment examination immediate, 2 hours and 3 hours at room temperature.
\end{abstract}

Key words: Time, Urinalisis, Urin.

\section{PENDAHULUAN}

Urin adalah cairan sisa yang diekskresikan oleh ginjal yang kemudian akan dikeluarkan dari dalam tubuh melalui proses urinari. Ekskresi urin diperlukan untuk membuang molekul-molekul sisa yang disaring oleh ginjal dan untuk menjaga hemostasis cairan tubuh $(1,2)$.

Indikasi tes urin adalah untuk tes saring pada tes kesehatan, keadaan patologik maupun sebelum operasi, menentukan infeksi saluran kemih terutama yang berbau busuk karena nitrit, leukosit atau bakteri, menentukan kemungkinan gangguan metabolisme misalnya diabetes melitus atau komplikasi kehamilan, menentukan berbagai jenis penyakit ginjal seperti glomerulonephritis, sindroma nefrotik dan pyelonephritis (1).

Tes urin telah lama dikerjakan dan sering dilakukan karena sampel mudah didapatkan dan teknik tes tidak begitu sulit. Tes urin rutin (urinalisis) bertujuan untuk menunjukkan adanya zat-zat yang dalam keadaan normal 
tidak terdapat dalam urin, atau menunjukkan perubahan kadar zat yang dalam keadaan normal terdapat dalam urin (3). Tes urin tidak hanya dapat memberikan fakta-fakta tentang ginjal dan saluran urin, tetapi juga mengenai faal berbagai organ dalam tubuh seperti hati, saluran empedu, pankreas, cortex adrenal, dII (4).

Urinalisis merupakan salah satu tes yang sering diminta oleh para klinis. Tes ini lebih populer karena dapat membantu menegakkan diagnosis, mendapatkan informasi mengenai fungsi organ dan metabolisme tubuh, juga dapat mendeteksi kelainan asimptomatik, mengikuti perjalanan penyakit dan pengobatan. Dengan demikian hasil tes urin haruslah teliti,tepat dan cepat. Permintaan urinalisis diindikasikan pada pasien dengan evalusi kesehatan secara umum, gangguan endokrin, gangguan pada ginjal atau traktus urinarius, monitoring pasien dengan diabetes, kehamilan, kasus toksikologi atau over dosis obat (5).

Tes urin terdiri dari pemeriksaan makroskopik, mikroskopik atau sedimen dan pemeriksaan kimia urin. Tes mikroskopik untuk melihat eritrosit, leukosit, sel epitel, torak, bakteri, kristal, jamur dan parasit. Pemeriksaan makroskopik adalah untuk menilai warna, kejernihan dan bau. Analisis makroskopik secara fisik meliputi tes warna, kejernihan, bau, berat jenis dan $\mathrm{pH}$. Analisis kimiawi meliputi tes protein, glukosa, keton, darah, bilirubin, urobilinogen, nitrit,dan lekosit esterase $(5,1)$.

Seringkali sampel urin datang ke laboratarium sudah tidak segar lagi dan telah dikeluarkan beberapa jam sebelumnya. Klinisi sering mengalami kesulitan untuk tepat mengirim sampel urin sehingga hasil yang diharapkan banyak tidak sesuai dengan kondisi klinis pasien. Padahal tes urin dapat banyak memberikan informasi tentang disfungsi ginjal. Bahan tes yang terbaik adalah urin segar kurang dari 1 jam setelah dikeluarkan. Penundaan antara berkemih dan urinalisis akan mengurangi validitas hasil, analisis harus dilakukan tidak lebih dari 4 jam setelah pengambilan sampel. Apabila dilakukan penundaan tes dalam 4 jam maka disimpan dalam lemari es pada suhu 2- $4^{\circ} \mathrm{C}$. Urin yang dibiarkan dalam waktu lama pada suhu kamar akan menyebabkan perubahan pada urin. Unsur-unsur berbentuk di urin (sedimen) mulai mengalami kerusakan dalam 2 jam $(3,5,6)$.

Pada penelitian terdahulu oleh Froom. Et al tahun 2000, menilai stabilitas urin saat penundaan waktu 
24 jam yang disimpan pada lemari pendingin memberikan hasil positif palsu pada beberapa parameter kimiawi urinalisis, yaitu protein, dan hasil negatif palsu pada leukosit dan eritrosit (7).

Penelitian ini bertujuan untuk melihat apakah ada pengaruh penundaan waktu terhadap sedimen urin yang diperiksa segera dengan sedimen urin yang mengalami penundaan tanpa perlakuan khusus.

\section{METODE PENELITIAN}

Jenis Penelitian

Jenis penelitian ini adalah penelitian cross sectional.

Tempat Dan Waktu Penelitian

Penelitian dilakukan selama Mei - Juli 2012 di Laboratorium Klinik Kimia Farma.

\section{Populasi dan Sampel Penelitian}

Populasi dalam penelitian ini adalah pasien check up yang datang ke laboratorium dengan permintaan pemeriksaan urinalisis. Berdasarkan data di Laboratorium Kimia Farma Makassar rata-rata pemeriksaan Urinalisis adalah 197 pasien perbulan. Pasien dengan nilai normal rata-rata 30-40 per bulan.

Teknik pengambilan sampel menggunakan teknik accidental sampling, yaitu bila ada pasien chek up melakukan pemeriksaan urinalisis dengan hasil normal dimasukkan sebagai sampel. Berdasarkan perhitungan dengan menggunakan rumus, jumlah sampel dalam penelitian ini adalah sebesar 37 orang.

\section{Kriteria Sampel}

Kriteria inklusi: semua pasien yang melakukan pemeriksaan urinalisis di Laboratorium kimia farma Makassar, laki-laki dan perempuan berumur 19-50 tahun, Setuju untuk diikutkan dalam penelitian dan menandatangani informed concent.

Kriteria eksklusi: sampel urin didapat lebih dari 1 jam setelah pengambilan, pasien yang mengalami kesulitan mengeluarkan urin.

\section{Prosedur Kerja}

\section{Persiapan sampel pemeriksaan :}

Sampel urin harus terhindar dari kontaminasi, wadah penampung hendaknya bersih dan kering serta diberi label.

\section{Prosedur pemeriksaan dengan metode Shih-Yung.}

Urine diambil sebanyak $12 \mathrm{ml}$ dan dimasukkan kedalam tabung yang telah dilengkapi dengan tutup tabung lalu disentrifus selama 5-10 menit pada kecepatan 1500-2000 rpm. Setelah itu lapisan atas urin dibuang sehingga didapatkan sedimen 0,5-1 ml kemudian ditambahkan 1 tetes pewarna Sternheimer-Malbin dan 
sedimen diresuspensikan. Diletakkan 1 tetes sedimen dengan menggunakan pipet penetes dalam kamar hitung. Diperiksa sedimen dibawah mikroskop dengan lensa objektif 40x untuk Lapangan Pandang Besar (LPB) dilaporkan jumlah leukosit, eritrosit dan sel epitel.

Sedimen didiamkan pada suhu kamar tanpa perlakuan khusus selama 2 jam lalu dilakukan pemeriksaan dengan cara sedimen diresuspensi kembali dengan mengetukkan jari perlahan pada dinding tabung. Diteteskan 1 tetes sedimen dengan menggunakan pipet tetes dalam kamar hitung. Diperiksa sedimen dibawah mikroskop dengan lensa objektif 40x untuk Lapangan Pandang Besar (LPB) dilaporkan jumlah leukosit, eritrosit dan sel epitel.
Untuk tes sedimen pada 3 jam berikutnya sedimen tetap didiamkan pada suhur kamar tanpa perlakuan khusus dan dilakukan pemeriksaan dengan cara sedimen diresuspensi kembali dengan mengetukkan jari perlahan pada dinding tabung. Diteteskan 1 tetes sedimen dengan menggunakan pipet tetes dalam kamar hitung. Diperiksa sedimen dibawah mikroskop dengan lensa objektif 40x untuk Lapangan Pandang Besar (LPB) dilaporkan jumlah leukosit, eritrosit dan sel epitel.

\section{Analisis Data}

Data yang diperoleh dilakukan uji statistik ANOVA (analisis of varian) dengan bantuan program SPSS 16 for windows. Dengan tingkat kepercayaan $95 \%$ dan alpha $(\alpha=0.05)$.

\section{HASIL PENELITIAN}

Table 1. Jenis Kelamin Pasien pada Pemeriksaan Mikroskopik metode Shih-Yung

\begin{tabular}{clcc}
\hline No & \multicolumn{1}{c}{ Jenis Kelamin } & Jumlah (n) & Persentasi (\%) \\
\hline 1. & Laki-laki & 18 & 48,6 \\
2. & Perempuan & 19 & 51,4 \\
\hline \multicolumn{2}{c}{ Total } & $\mathbf{3 7}$ & $\mathbf{1 0 0}$ \\
\hline
\end{tabular}

Berdasarkan tabel 1 di atas pasien dengan jenis kelamin lebih banyak perempuan jumlahnya dibandingkan laki-laki, yaitu dari 37 orang pasien yang diperiksa sedimen urin terdapat 19 orang perempuan $(51,4 \%)$ dan 18 orang perempuan $(48,6 \%)$.
Hasil rata-rata jumlah sedimen urin pada pemeriksaan secara mikroskopik terhadap sampel urin pasien chek up urinalisis dengan perbedaan waktu pemeriksaan sampel urin segera $(<1$ jam), 2 jam, dan 3 jam dapat dilihat pada table 2 di bawah ini: 
Tabel 2. Jumlah rata-rata sedimen urin pada penundaan waktu terhadap hasil urinalisis sedimen urin

\begin{tabular}{|c|c|c|c|c|c|}
\hline NO & $\begin{array}{c}\text { Sedimen } \\
\text { Urin }\end{array}$ & $\begin{array}{l}\text { Penundaan waktu } \\
\text { (jam) }\end{array}$ & $\begin{array}{l}\text { Jumlah } \\
\text { sampel }\end{array}$ & Rata - rata & $\begin{array}{l}\text { Std. } \\
\text { Deviasi }\end{array}$ \\
\hline \multirow{3}{*}{1.} & \multirow{3}{*}{ Leukosit } & segera & 37 & 1,29 & 0,905 \\
\hline & & 2 jam & 37 & 1,05 & 0,777 \\
\hline & & 3 jam & 37 & 0,89 & 0,681 \\
\hline \multirow{3}{*}{2.} & \multirow{3}{*}{ Eritrosit } & segera & 37 & 0,70 & 0,581 \\
\hline & & 2 jam & 37 & 0,59 & 0,481 \\
\hline & & 3 jam & 37 & 0,48 & 0,421 \\
\hline \multirow{3}{*}{3.} & \multirow{3}{*}{ Sel Epitel } & segera & 37 & 9,70 & 9,192 \\
\hline & & 2 jam & 37 & 8,51 & 7,957 \\
\hline & & 3 jam & 37 & 7,54 & 6,907 \\
\hline
\end{tabular}

Berdasarkan tabel 2 di atas, diperoleh nilai rata-rata leukosit, eritrosit, dan epitel menggunakan metode Shih-Yung mengalami penurunan pada pemeriksaan 2 jam dan 3 jam, dimana pada pemeriksaan tersebut masih menunjukan batas normal adanya leukosit, eritrosit dan sel epitel dalam urin. Untuk melihat pengaruh dari hasil pemeriksaan sedimen urin secara mikroskopik dengan penundaan waktu pemeriksaan sampel urin segera, 2 jam, dan 3 jam, maka dilakukan uji statistik menggunakan uji One Way Anova dengan tingkat kepercayaan 95\% dengan bantuan SPSS 16 for windows, yang hasil pengujiannya dapat dilihat pada tabel di bawah ini :

Tabel 3. Data uji statistik ANOVA hasil Pengaruh Penundaan Waktu Terhadap Hasil Tes Sedimen Urin

\begin{tabular}{|c|c|c|c|c|c|}
\hline $\begin{array}{c}\text { Parameter pemeriksaan } \\
\text { sedimen urin }\end{array}$ & $\begin{array}{c}\text { Variasi pemeriksaan } \\
\text { sedimen urin }\end{array}$ & $\mathbf{N}$ & $\mathbf{F}$ & $\begin{array}{l}\text { Signifikan } \\
(\mathrm{P})\end{array}$ & $\alpha$ \\
\hline Leukosit & $\begin{array}{c}\text { Segera } \\
2 \text { jam } \\
3 \text { jam }\end{array}$ & $\begin{array}{l}37 \\
37 \\
37\end{array}$ & 2,390 & $\left.0,096^{*}\right)$ & 0,05 \\
\hline Eritrosit & $\begin{array}{l}\text { Segera } \\
2 \text { jam } \\
3 \text { jam }\end{array}$ & $\begin{array}{l}37 \\
37 \\
37\end{array}$ & 1,769 & 0,176 & 0,05 \\
\hline Sel Epitel & $\begin{array}{l}\text { Segera } \\
2 \text { jam } \\
3 \text { jam }\end{array}$ & $\begin{array}{l}37 \\
37 \\
37\end{array}$ & 0,666 & 0,516 & 0,05 \\
\hline
\end{tabular}

terlihat bahwa tidak ada pengaruh signifikan terhadap penundaan waktu pada pemeriksaan sedimen urin.
Berdasarkan hasil penelitian terhadap pengaruh penundaan waktu terhadap hasil urinalisis sedimen urin 
dari 37 subjek penelitian yang diperiksa di laboratorium klinik Kimia Farma Makassar terdapat 18 orang laki-laki $(48,6 \%)$ dan 19 orang perempuan $(51,4 \%)$ ini terlihat pada table 1. Dalam penelitian ini kelompok perempuan lebih banyak sebagai subjek penelitian dibandingkan kelompok laki-laki, karena saat dilakukan penelitian ternyata kelompok perempuan lebih banyak melakukan pemeriksaan urinalisis secara mikroskopik di Laboratorium Klinik Kimia Farma Makassar.

Tes sedimen urin (mikroskopik) digunakan untuk mengidentifikasi jenis atau unsur sedimen urin, yaitu eritrosit, leukosit, dan sel epitel,. Tes ini digunakan untuk mendeteksi infeksi saluran kemih dan memantau perjalanan penyakit pada kelainan ginjal dan saluran kemih. Pada penelitian ini tes sedimen urin menggunakan metode Shih-Yung. Metode ini dapat menunjukkan ketelitian dan ketepatan lebih akurat, dapat mengurangi kontaminasi karena tabung sentifus, kamar hitung, dan pipet yang disposible sehingga hasil yang diperoleh lebih baik. Untuk pemeriksaan sedimen urin dibutuhkan urin sewaktu yang masih segar dalam penampungan yang tertutup rapat dan tidak terkontaminasi. Pemeriksaan harus dilakukan secepat mungkin, paling lambat 1 jam setelah urin ditampung. Melakukan penundaan pemeriksaan dapat menjadi sumber kesalahan, sehingga hasil yang diharapkan tidak sesuai dengan kondisi klinis pasien. Unsur-unsur berbentuk (sedimen) dalam urin mulai rusak dalam waktu 2 jam dan bila dibiarkan lama dalam suhu kamar akan terjadi lisis sel serta torak dan urin akan berubah menjadi alkalis. (8)

Dari hasil penelitian yang dapat dilihat pada tabel 2, yaitu memberikan nilai rata-rata jumlah unsur sedimen. Pada pemeriksaan segera nilai ratarata leukosit $=1,29 / \mu \mathrm{l} \quad(\mathrm{SD}=0,905)$, eritrosit $=0.70 / \mu \mathrm{l} \quad(\mathrm{SD}=0,581)$, sel epitel $=9.70 /$ LPB $(S D=9,192) . \quad$ Pada penundaan waktu pemeriksaan 2 jam nilai rata-rata leukosit $1,05 / \mu \mathrm{l}$ $(S D=0,777), \quad$ eritrosit $=0,58 / \mu l$ $(\mathrm{SD}=0,481)$, sel epitel $=8.51 / \mathrm{LPB}$ $(S D=7,957)$ dan penundaan waktu pemeriksaan 3 jam nilai rata-rata leukosit $0,89 / \mu \mathrm{l}(\mathrm{SD}=0,885)$, eritrosit $=$ $0,48 / \mu \mathrm{l} \quad(S D=0,421)$, sel epitel = 7,54/LPB (SD=6,907). Dari data diatas menunjukkan adanya penurunan hasil dari pemeriksaan leukosit, eritrosit, dan epitel pada sedimen urin dari pemeriksaan tunda 2 jam dan 3 jam.

Hasil pemeriksaan sedimen urin leukosit dan eritrosit dengan metode 
Shih-Yung masih menunjukkan batas normal leukosit dalam urin pasien yaitu $<10 / \mu \mathrm{L}$ dan eritrosit normal $<3 / \mu \mathrm{L}$. Sedangkan pelaporan menurut JCCLS pada sel epitel per lapangan pandang besar masih dalam batas normal.

Berdasarkan analisis statistika menggunakan uji one way anova (analisis of varian) terhadap variasi pemeriksaan urin pasien check-up urinalisis. Perlakuan pemeriksaan terhadap urin segera periksa, tunda 2 jam,dan 3 jam pada table 3 menunjukkan hasil pemeriksaan sedimen urin leukosit $F$ hitung 2,390< $F$ tabel 3,26 dengan signifikan (P) $0,096>0,05$ maka Ho diterima berarti tidak terdapat pengaruh yang signifikan terhadap penundaan waktu pada pemeriksaan sedimen urin. Pada pemeriksaan sedimen urin eritrosit didapatkan $\mathrm{F}$ hitung $1,769<\mathrm{F}$ table 3,26 dengan signifikan $(P) \quad 0,176>$ 0.05 maka Ho diterima berarti tidak terdapat pengaruh yang signifikan terhadap penundaan waktu pada pemeriksaan sedimen urin. Begitu pula pada sel epitel dimana didapatkan $\mathrm{F}$ hitung $0,666<F$ table 3,26 dan signifikan $(P) 0,516>0.05$ yang berarti Ho diterima dan Ha ditolak.

Pada penelitian terdahulu oleh Froom. Et al tahun 2000, menilai stabilitas urin saat penundaan waktu
24 jam yang disimpan pada lemari pendingin memberikan hasil positif palsu pada beberapa parameter kimiawi urinalisis yaitu protein, hasil negatif palsu pada leukosit dan eritrosit. (9)

Penelitian yang berkaitan dengan sedimen urin juga dilakukan oleh Linda Rosita tahun 2009, pengaruh penundaan waktu terhadap urinalisis memberikan hasil pada parameter kimiawi urinalisis yang berbeda secara statistik dengan penundaan waktu 2 jam $(p<0.05)$ adalah $\mathrm{pH}$, glukosa dan keton. Penundaan waktu 2 jam pada urinalisis dapat mengakibatkan penurunan hasil kadar glukosa dan keton sedangkan parameter yang terjadi peningkatan yaitu $\mathrm{pH}$, eritrosit, dan Urobilinogen dan untuk penyimpanan pada suhu 2-4 ${ }^{\circ} \mathrm{C}$ dapat menstabilkan $\mathrm{pH}$, Urobilinogen, dan nitrit. (3)

\section{KESIMPULAN}

Berdasarkan penelitian ini, dapat disimpulkan bahwa tes sedimen urin leukosit, eritrosit dengan metode Shih-Yung dan sel epitel berdasarkan JCCLS dengan melakukan penundaan waktu pemeriksaan 2 jam dan 3 jam, masih dalam batas normal adanya leukosit, eritrosit, dan sel epitel dalam urin dan tidak terdapat pengaruh yang 
signifikan terhadap hasil pemeriksaan sedimen urin leukosit, eritrosit dan sel epitel pada pemeriksaan segera, tunda 2 jam, dan 3 jam.

\section{DAFTAR PUSTAKA}

Hardjoeno, Yetty Fauza, Benny Rusli. Interpretasi hasil laboratorium diagnostik. Penerbit Buku Universitas Hasanuddin. Makassar. 2006

Price SA dan Wilson LM. Patofisiologi konsep klinis proses-proses Penyakit. Edisi ke 6. Penerbit EGC. Jakarta. 1993.

Rosalita, L. Pengaruh Penundaan Waktu Terhadap Hasil Urinalisis. Departemen Patologi Klinik fakultas Kedokteran Universitas Islam Indonesia Yogyakarta. (serial on the internet). 12 februari 2012. http://isjd.pdii.lipi.go.id

Gandasoebrata R. Penuntun Laboratorium Klinik. Dian Rakyat. Jakarta. 2007

Hardjoeno, H dan Fitriani. Substansi Dan Cairan Tubuh. Lembaga
Penerbitan Universitas Hasanuddin. 2007

Sacher, RA., McPherson RA.,. Tinjauan klinis hasil pemeriksaan Laboratorium, E/11. EGC.Jakarta , 2004. Hal 589-591

Froom, P dkk. Stability Of Common Analytes in Urine Refrigerated for $24 \mathrm{~h}$ Before Automated Analysis by Test Strip. Clinical chemistry. 2000. (serial on the internet).7 februari 2012. http://www.clinchem.org

Widman, F, K. Tinjauan Klinis atas Hasil Pemeriksaan Laboratorium. Ed. 9 . Terjemahan oleh Boedina KS, Soebrata R \& Latu J. Penerbit Buku Kedokteran. EGC. Jakarta.1995

Wirawan R, Immanuel S, Dharma R. Penilaian Hasil Pemeriksaan Urine (Cermin Dunia Kedokteran) No.30. Jakarta. 2011. (serial on the internet). $7 \quad$ februari 2012. http://www.smallcrab.com 